\title{
The Influence of Complex Doping on Kinetics of Decomposition and Thermal Stability of Mg-Based Mechanical Alloys
}

\author{
Frantsevych Institute for Problems of Materials Science, National Academy of Sciences of Ukraine, Kyiv, \\ Ukraine, e-mail:dobersh2017@ukr.net
}

\begin{abstract}
Mechanical alloys (MAs) were synthesized by the method of reactive mechanical alloying. At a hydrogen pressure of $0.1 \mathrm{MPa}$, with the use of thermal desorption spectroscopy, the thermal stability, the kinetics of hydrogen desorption from the hydride phase $\mathrm{MgH}_{2}$ of the obtained MAs were studied. It has been established that the complex doping by of $\mathrm{Fe}, \mathrm{Si}$, $\mathrm{Ti}$, leads to a significant improvement in the hydrogen desorption from the hydride phase $\mathrm{MgH}_{2}$ of MA synthesized by the RMA. Hydrogen capacity $\mathrm{C}_{\mathrm{H}}$ of MA after reactive grinding for $20 \mathrm{~h}$. was found to be equal to $5.7 \%$ wt. Due to this alloying, the decrease in the thermodynamic stability of $\mathrm{MgH}_{2}$ is not established. The tested materials showed a high potential as hydrogen storage alloys especially for stationary application.
\end{abstract}

Keywords: mechanical alloy; hydrogen sorption properties; thermal stability; kinetics.

Стаття поступила до редакиії 13.11.2019; прийнята до друку 15.12.2019.

\section{Introduction}

Hydrogen is a unique energy source having three times higher energy than traditional fuels. It is easy to be stored and transported; it can be very efficiently converted into electricity, for example, in fuel cells, while the only waste is water. The development of hydrogen energy promises a significant breakthrough in addressing such important issues as creating environmentally tolerant energy systems, reducing environmental pollution, improving energy security, developing infrastructure for road transport on hydrogenoxygen fuel cells, etc.

Magnesium hydride-based materials have attracted significant attention. There exist a few magnesium alloys, the composites on its basis that are most promising in terms of the optimal combination of properties: high hydrogen capacity, relatively low hydrogen desorption temperature, high kinetic characteristics, acceptable cost. It is known that in order to use hydrogen permeation material in hydrogen storage systems on a car board the hydrogen capacity of 5 $6 \mathrm{wt}$ \% is needed. The decomposition temperature of the hydride phase is not higher than $150-200{ }^{\circ} \mathrm{C}$.
Despite the attention of scientists to magnesium hydride, methods used for its production, studies of its properties, application of the hydride in the automotive industry (as a hydrogen-accumulating material) remains complicated due to high temperature $\left(300{ }^{\circ} \mathrm{C}\right.$ at 1 bar $\left.\mathrm{H}_{2}\right)$ and slow kinetics of dissociation. The main problem is due to the necessity of decreasing the temperature of decomposition with simultaneous increase in its rate and preservation of the high hydrogen capacity and cyclic resistance of hydride phase $\mathrm{MgH}_{2}$ of mechanical alloys to get a complex of required characteristics. Most often, the problem of simultaneous formation of several desired characteristics of $\mathrm{MgH}_{2}$ is realized by the mechanical dispersion of commercial hydride in the presence of various catalytic admixtures (e.g., transition $3 \mathrm{~d}$ - and 4d-metals [1-9] and their oxides and fluorides, intermetallic compounds, and admixtures of the nontransition metals, such as $\mathrm{Al}, \mathrm{Cu}, \mathrm{Zn}$, In, and $\mathrm{Sn}$, graphite, etc.) or by the procedure of grinding of powders of metallic $\mathrm{Mg}$ with these admixtures in hydrogen or in atmospheres of inert gases with subsequent hydrogenation from the gas phase [1-31].

In order to decrease the thermodynamic stability 
of $\mathrm{MgH}_{2}$, it is conventional to use mechanical alloys in the form of solid solutions in magnesium of one or several metals capable of decreasing the enthalpy of formation/decomposition of $\mathrm{Mg}(\mathrm{Me}) \mathrm{H}_{2} \quad$ [32-39]. According to the theoretical predictions [5], the hydrides of solid solutions of $\mathrm{Al}, \mathrm{Ti}, \mathrm{Fe}, \mathrm{Ni}, \mathrm{Cu}$, and $\mathrm{Nb}$ in magnesium should have lower enthalpies of formation and decompose at temperatures lower than that of pure $\mathrm{MgH}_{2}$. It was shown that the thermodynamic stability of these hydrides of solid solutions depends on the procedures and conditions of their production [32-36]. Thus, the decomposition of the hydride phase $\mathrm{Mg}(\mathrm{In}) \mathrm{H}_{2}$ of the mechanical alloy obtained as a result of high-energy grinding of a powder of $\mathrm{MgH}_{2}$ with 10 at. \% In in hydrogen under a pressure of 150 bar originates at $262.3^{\circ} \mathrm{C}$ under a hydrogen pressure of $1 \mathrm{bar}$ in the reactor [35]. At the same time, the analysis of the PCT (pressurecomposition-temperature) curves [35] for the hydride of a solid solution of aluminum in magnesium formed by grinding a mixture of 90 at. $\% \mathrm{MgH}_{2}$ with 10 at. $\%$ Al in hydrogen under a pressure of 150 bar does not reveal the indicated effect of destabilization of the hydride phase $\mathrm{Mg}(\mathrm{Al}) \mathrm{H}_{2}$ during dehydrogenation. In [39-44], silicon was used to destabilize $\mathrm{MgH}_{2}$ hydride. Silicon forms relatively strongly bound compounds with $\mathrm{Mg}\left(\mathrm{Mg}_{2} \mathrm{Si}\right.$ forms upon dehydrogenation of $\mathrm{MgH}_{2}$ for the $\mathrm{MgH}_{2} / \mathrm{Si}$ system) that reduces dehydrogenation enthalpies and increases equilibrium hydrogen pressures. Calculations using tabulated thermodynamic parameters predict an equilibrium pressure of 1 bar at approximately $20{ }^{\circ} \mathrm{C}$ and 100 bar at approximately $150{ }^{\circ} \mathrm{C}$. However, the kinetics at $150{ }^{0} \mathrm{C}$ are too slow for direct hydrogenation /dehydrogenation. The possibility of increasing the solidstate reaction rate of $\mathrm{MgH}_{2}$ with $\mathrm{Si}$ by modifying the mixture preparation method and adding chemical elements or compounds, such as $\mathrm{Ti}, \mathrm{Ni}, \mathrm{NbF}_{5}, \mathrm{TiO}_{2}$, $\mathrm{Cr}_{2} \mathrm{O}_{3}$, was investigated in [40, 42]. It has been shown that these catalysts can effectively speed up the destabilization reaction at the beginning.

In this article with the aim of lowering the temperature, improvement of the kinetics of the decomposition of stoichiometric $\mathrm{MgH}_{2}$ hydride, the possibility of its complex doping by $\mathrm{Si}, \mathrm{Ti}, \mathrm{Fe}$ using the method of reactive mechanochemical alloying (RMA) has been investigated. A number of mechanical alloyscomposites (MAs) of $\mathrm{Mg}$ with additions of a different composition of titanium, iron and silicon were synthesized. The phase composition, hydrogensorption properties, thermal stability and desorption kinetics of hydrogen, microstructure have been investigated employing the X-ray diffraction (XRD), thermodesorption spectroscopy (TDS), scanning electron microscopy (SEM) methods.

For comparison, we synthesized an additional composite alloy in the same condition that were used for obtaining the MAs samples, without any additives. Choosing $\mathrm{Ti}$ and $\mathrm{Fe}$, we take into account the fact that these transition metals have catalytic properties. In the course of reactive mechanical fusion, they may improve significantly the kinetics of hydrogenation of magnesium playing the role of dispersing agents and noticeably affect the thermodynamic stability of the
$\mathrm{MgH}_{2}$ phase formed in the course of synthesis according to the theoretical prediction [5]. In order to destabilize $\mathrm{MgH}_{2}$, silicon is also included in the additive composition.

\section{Experimental part}

The mechanical alloys-composites has been synthesized by reactive grinding in hydrogen of powders: $\mathrm{Mg}+5$ wt. $\% \mathrm{Si}+5$ wt. $\% \mathrm{Ti}+2$ wt. $\% \mathrm{Fe}$ (further MA1), $\mathrm{Mg}+5$ wt. $\% \mathrm{Si}+5$ wt. $\% \mathrm{Fe}+2$ wt. $\%$ Ti (MA2), $\mathrm{Mg}+10$ wt. $\% \mathrm{Si}+2$ wt. $\% \mathrm{Ti}+2$ wt. $\% \mathrm{Fe}$ (MA3), pure $\mathrm{MgH}_{2}$ (MA4). The main aim of this study was to obtain the above mentioned MA1-MA4 mechanical alloys and explore the processes of hydrogen desorption of $\mathrm{MgH}_{2}$ hydride phase (both immediately after mechanical synthesis and after the first hydrogenation /dehydrogenation cycles). Moreover, it was necessary to find out if the reduction of $\mathrm{MgH}_{2}$ hydride phase formation enthalpy takes place. Consequently, the equilibrium temperature decrease of its decomposition at a constant hydrogen pressure of $0.1 \mathrm{MPa}$ due to the selected alloying elements and the obtained method was also studied. The selected alloying elements influence on $\mathrm{MgH}_{2}$ decomposition kinetics was the aim of the investigation as well

The commercial powders of $\mathrm{Mg}, \mathrm{Ti}, \mathrm{Fe}, \mathrm{Si}$ with a purity of $99.98 \%$ and particles sizes of $100 ; 3 ; 6,7$; $10 \mu \mathrm{m}$, respectively, have been used as raw materials. The mechanical fusion by reactive grinding of the mixture of powders of MA1-MA4 composition, was realized in a RETCH100 ball mill with steel balls in a hydrogen atmosphere (under a hydrogen pressure of 1 $\mathrm{MPa}$, for a velocity of rotation of $450 \mathrm{rot} / \mathrm{min}$ and a duration of grinding of $20 \mathrm{~h}$ ). The ratio of the metallic balls mass and the treated mixture of powders was 20:1. Milling was interrupted every $50 \mathrm{~min}$ to allow the vial to cool down to room temperature followed by the monitoring of the current state of hydrogen absorption. We use one and the same conditions of synthesis for all MAs under consideration that allows making a proper comparison of different alloying elements effect on temperature and the kinetics of $\mathrm{MgH}_{2}$ hydride phase decomposition of synthesized MAs. Conditions of synthesis of all MA samples derived by direct hydrogenation from the gas phase were also the same. After the MA synthesis and obtaining the first hydrogen desorption curve, the sample was not removed from the reactor. At temperature of $400{ }^{\circ} \mathrm{C}$ the reactor was filled with hydrogen until hydrogen pressure was $6 \mathrm{MPa}$ and during the sample cooling together with the furnace its first (and subsequent) hydrogenation from the gas phase took place.

Microstructures of the initial powder mixture and the synthesized composite alloys were studied using a SuperProbe 733 scanning electron microscope. For the X-ray phase diffraction analysis of specimens, we used a DRON-3M diffractometer. The X-Ray patterns were obtained employing $\mathrm{CuK} \alpha$-radiation with a graphite monochromator. The profiles of diffraction lines were plotted with scanning steps of $0.1^{0}$ and with exposure at each point of the spectrum over $20 \mathrm{sec}$. The diffraction 
patterns were analyzed using fullprof software Powder Cell 2.4 (https: // powdercell-for-windows. software. informer. com $/ 2.4 /$ ).

By the method of thermal desorption spectroscopy with a computerized automatic installation, we studied the influence of alloying elements on the hydrogen sorption properties, thermal resistance, the kinetics of hydrogen desorption from the $\mathrm{MgH}_{2}$ hydride phase. This installation allows to plot the isobars of desorption / resorption of hydrogen under various pressures in the reactor and to perform the hydrogenation / dehydrogenation of specimens under pressures up to 10 $\mathrm{MPa}$ and temperatures being in the range from room temperature to $1200{ }^{0} \mathrm{C}$. The details are presented in Refs. [29].
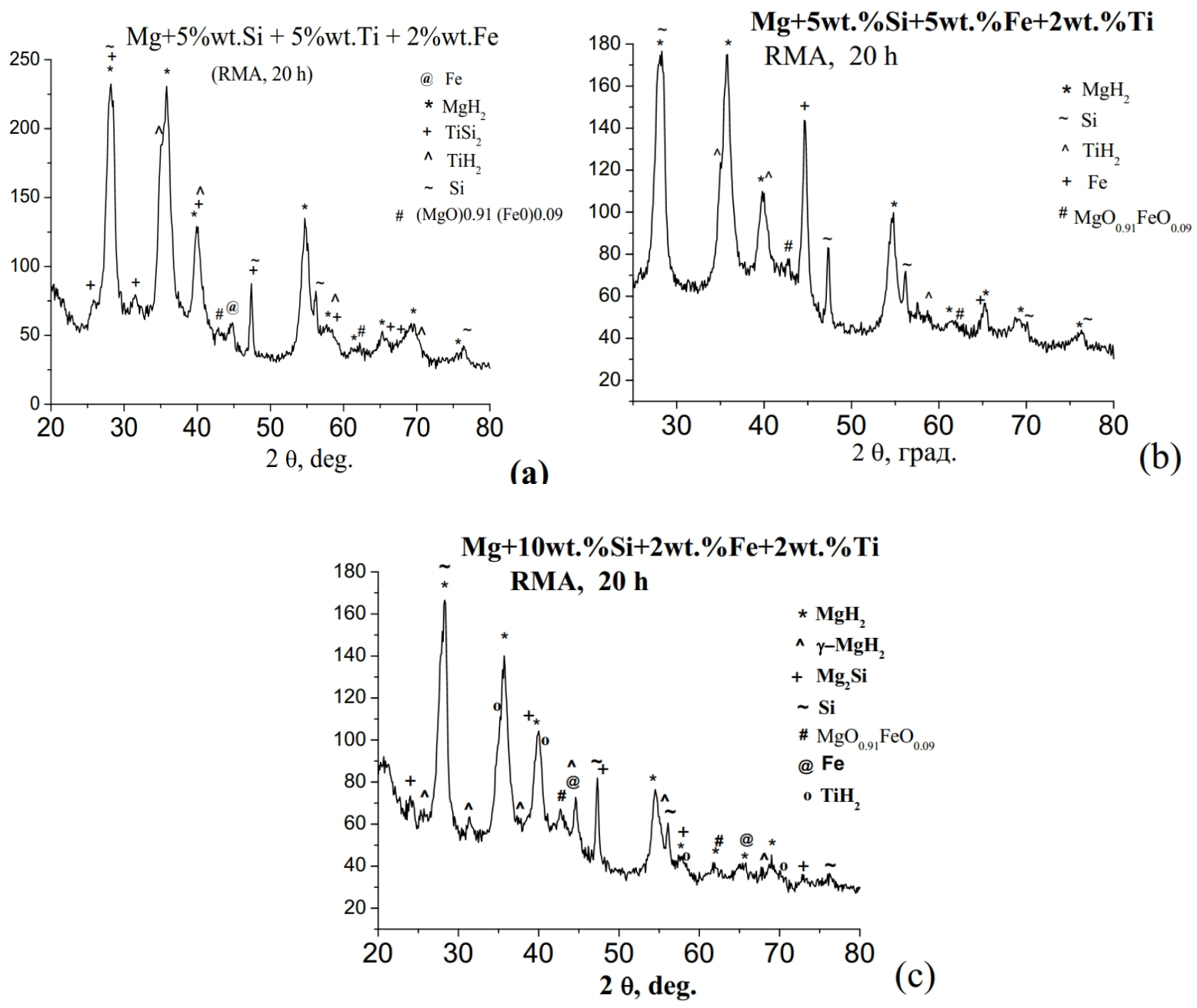

Fig. 1. X-ray diffraction pattern of specimens of the mechanical alloys: a - MA1, b - MA2, c - MA3 obtained by reactive mechanical alloying.

Table 1

Phase compositions and properties of MA in the case of its first heating after RMA and of its first hydrogenation from the gaseous phase (HGM)

\begin{tabular}{|c|c|c|c|}
\hline \multirow{2}{*}{ Mechanical alloy-composite wt.\% } & \multicolumn{2}{|c|}{ Phase compositions } & \multirow{2}{*}{$\begin{array}{c}\mathrm{D}_{\text {part. }}, \\
\mu \mathrm{m} \\
\text { RMA }\end{array}$} \\
\hline & RMA & HGM & \\
\hline MA1 $(\mathrm{Mg}+5 \mathrm{Si}+5 \mathrm{Ti}+2 \mathrm{Fe})$ & $\begin{array}{c}\mathrm{Fe}, \mathrm{Si}, \mathrm{MgH}_{2,} \mathrm{TiSi}_{2}, \mathrm{TiH}_{2}, \\
\mathrm{MgO}_{0.91} \mathrm{FeO}_{0,09}\end{array}$ & $\begin{array}{c}\mathrm{Fe}, \mathrm{Si}, \mathrm{MgH}_{2} \\
\mathrm{TiH}_{2}, \mathrm{MgO}_{0,91} \mathrm{FeO}_{0,09} \\
\text { after } 8 \text { hydr. }\end{array}$ & 0,6 \\
\hline $\mathrm{MA} 2(\mathrm{Mg}+5 \mathrm{Si}+5 \mathrm{Fe}+2 \mathrm{Ti})$ & $\begin{array}{l}\mathrm{Fe}, \mathrm{Si}, \mathrm{MgH}_{2}, \mathrm{TiH}_{2}, \\
\mathrm{MgO}_{0,91} \mathrm{FeO}_{0,09} \\
\end{array}$ & $\begin{array}{l}\mathrm{Fe}, \mathrm{MgH}_{2}, \mathrm{MgO}_{2} \\
\mathrm{Mg}_{2} \mathrm{Si} \text { after 4hydr. }\end{array}$ & 0,4 \\
\hline MA3 $(\mathrm{Mg}+10 \mathrm{Si}+2 \mathrm{Fe}+2 \mathrm{Ti})$ & $\begin{array}{c}\mathrm{Fe}, \mathrm{Si}, \mathrm{MgH}_{2}, \gamma-\mathrm{MgH}_{2} \\
\mathrm{Mg}_{2} \mathrm{Si}, \mathrm{TiH}_{2}, \mathrm{MgO}_{0,91} \mathrm{FeO}_{0,09}\end{array}$ & $\begin{array}{c}\mathrm{Fe}, \mathrm{MgH}_{2}, \mathrm{Mg}_{2} \mathrm{Si}, \mathrm{TiH}_{2} \\
\mathrm{MgO}_{0,91} \mathrm{FeO}_{0,09} \\
\text { after } 5 \text { hydr. }\end{array}$ & 0,3 \\
\hline MA4 & $\mathrm{Mg}, \mathrm{MgH}_{2}, \mathrm{MgO}_{0,91} \mathrm{FeO}_{0,09}$ & $\mathrm{Mg}, \mathrm{MgH}_{2}, \mathrm{MgO}_{0,91} \mathrm{FeO}_{0,09}$ & 0,7 \\
\hline
\end{tabular}




\section{Results and discussion}

\subsection{XRD analysis and SEM characterization of the samples.}

Fig. 1 shows XRD pattern of the MA1-MA3 samples derived by reactive mechanical alloying (RMA) and Fig.2 - after the gas phase hydrogenation (GPH) mechanical alloys. The information on the phase composition of the MA specimens obtained by RMA and after GPH is presented in Table 1. As Table 1 shows, all mechanical alloys (MA1-MA3) are composites, as a result of reactive mechanical alloying. In addition to $\mathrm{MgH}_{2}$, they contain $\mathrm{Si}, \mathrm{Fe}$ phases, as well as new crystalline phases which are not parts of the initial mixture of mechanical alloys powders and are magnesium oxides, magnesium compounds with alloying elements $\left(\mathrm{Mg}_{2} \mathrm{Si}\right.$ in the case of MA3) and compounds $\mathrm{TiH}_{2}$ and $\mathrm{TiSi}_{2}$. After the first hydrogenation / dehydrogenation cycles from the gas phase, all MAs reveal changes in the composite phase composition. In the case of $\mathrm{MA} 1, \mathrm{Ti}_{2} \mathrm{Si}$ phase is already absent, in the case of MA2 and MA3, $\mathrm{Mg}_{2} \mathrm{Si}$ phase appeared instead of the pure-silicon phase. The parameters of crystal lattices and volume of unit cells for $\beta-\mathrm{MgH}_{2}$ hydride phase of MAs (Table 2) have been determined by the full-profile Rietveld method using Powder Cell 2.4 program.

Fig. 3 shows the microstructure and morphology of

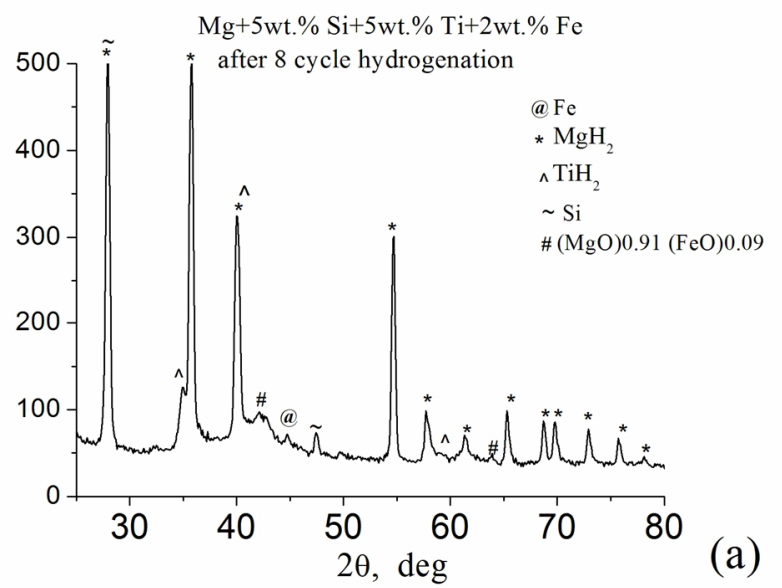

Table 2

Crystal structure data (unit cell parameters: a, c - $\AA$; V - $\AA^{3}$ ) for $\mathrm{MgH}_{2}$ Hydride phase composites

\begin{tabular}{|c|l|}
\hline $\begin{array}{c}\text { Mechanical alloy-composite, } \\
\text { wt. } \%\end{array}$ & Unit cell parameters \\
\hline MA1 $(\mathrm{Mg}+5 \mathrm{Si}+5 \mathrm{Ti}+2 \mathrm{Fe})$ & $\begin{array}{l}\mathrm{a}=4.5011 \mathrm{~V}=2.025 \\
\mathrm{c}=3.0413\end{array}$ \\
MA2 $(\mathrm{Mg}+5 \mathrm{Si}+5 \mathrm{Fe}+2 \mathrm{Ti})$ & $\begin{array}{l}\mathrm{a}=4.5148 \mathrm{~V}=1.616 \\
\mathrm{c}=3.0430\end{array}$ \\
MA3 $(\mathrm{Mg}+10 \mathrm{Si}+2 \mathrm{Fe}+2 \mathrm{Ti})$ & $\begin{array}{l}\mathrm{a}=4.5123 \\
\mathrm{~V}=61.2557 \\
\mathrm{c}=3.0345\end{array}$ \\
MA4 & $\begin{array}{l}\mathrm{a}=4.5223 \mathrm{~V}= \\
61.684 \\
\mathrm{c}=3.0157\end{array}$ \\
\hline
\end{tabular}

the three above mentioned MAs. It is well seen that after mechanical dispersion, the powders represent a mixture of particles with their sizes from 0.1 to $0.8 \mu \mathrm{m}$ and agglomerates with sizes from 2 to $5 \mu \mathrm{m}$. Based on our experimental data, the average particle size, which in turn consists of nanorods (the average size is $9-12 \mathrm{~nm}$ ) in MA1, MA2, MA3 is $0.6,0.4,0.3 \mu \mathrm{m}$ respectivelly. After repeated hydrogenation/dehydrogenation of powders from the gas phase, as shown by the study of their

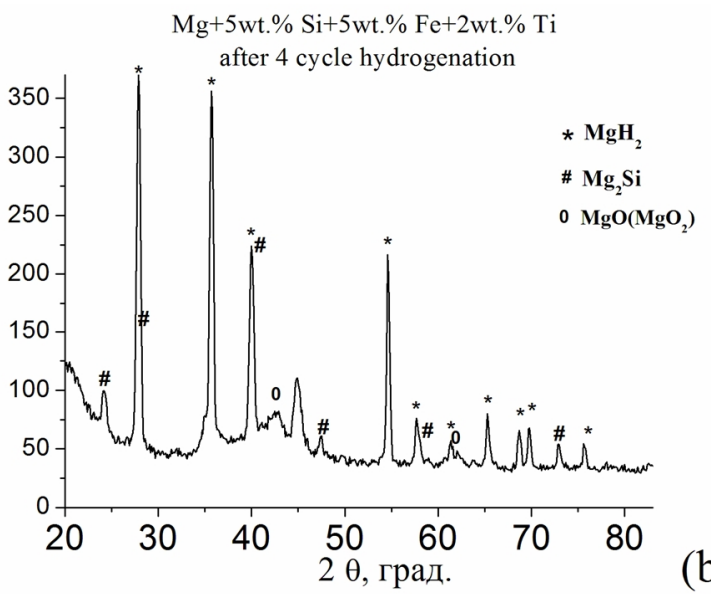

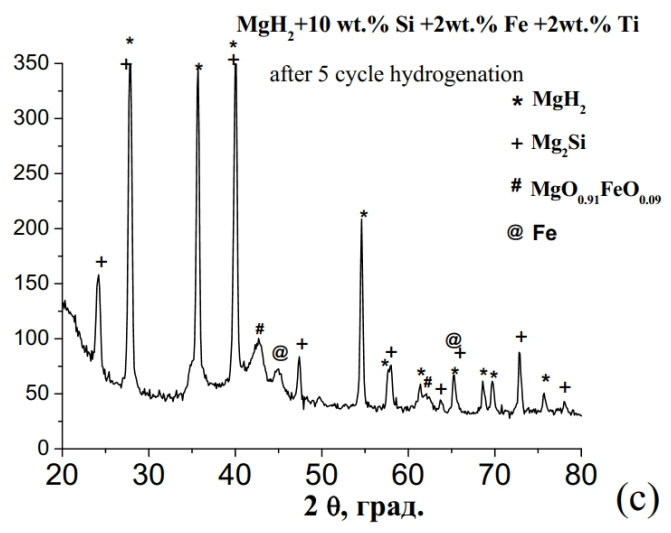

Fig. 2. X-ray diffraction pattern of specimens of the mechanical alloys after hydrogenation from the gaseous phase: a - MA1, b - MA2, c - MA3. 


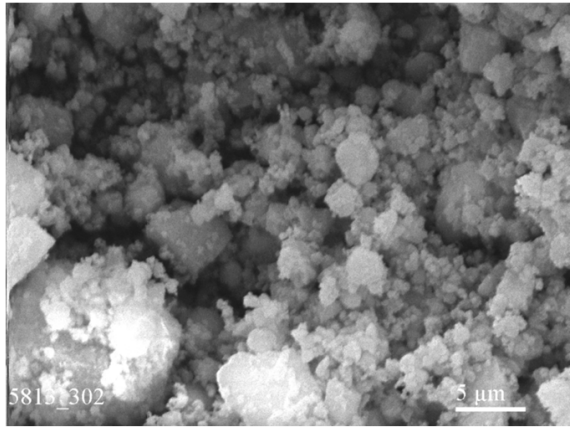

a

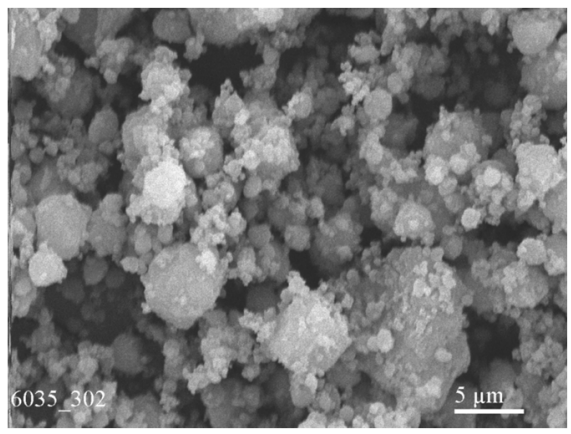

c

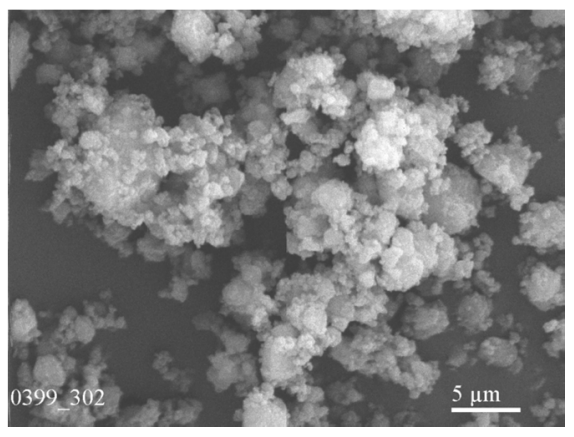

e

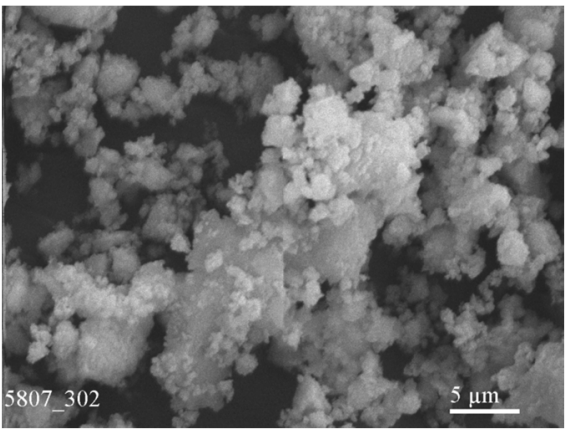

b

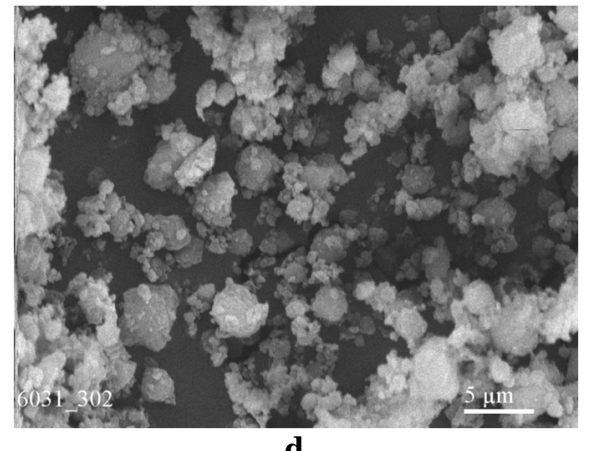

d

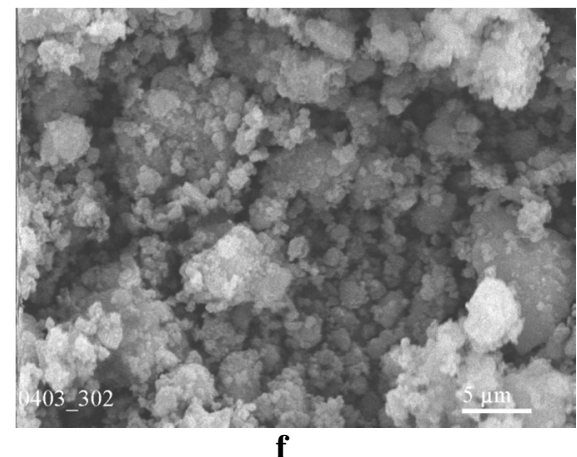

Fig. 3. Microstructures of mechanical alloys: a, b- $\mathrm{Mg}+5 \mathrm{wt} \% \mathrm{Si}+5 \mathrm{wt} \% \mathrm{Ti}+2 \mathrm{wt} \% \mathrm{Fe} ; \mathrm{c}$,

d $-\mathrm{Mg}+5$ wt. $\% \mathrm{Si}+5$ wt. $\% \mathrm{Fe}+2$ wt. $\% \mathrm{Ti} ;$ e, f $-\mathrm{Mg}+10$ wt. $\% \mathrm{Si}+2$ wt. $\% \mathrm{Fe}+2$ wt.\% Ti.

a, c, e - after synthesis by RMA method 20 h.; b, d, f - after first cycles of hydrogenation from the gas phases.

microstructure, the average particle size decreases (Fig. $3 \mathrm{~b}$ ) and the average grain size increases to $50-70 \mathrm{~nm}$ due to cyclic heating/cooling. These data correlate with the data of the X-ray phase analysis. Comparing the diffraction reflexes of the MA sample prior and after its cycling, one can observe, in the latter case, their noticeable narrowing (Fig. 1 and Fig. 2).

Comparing the microstructure of all mechanical alloys with different content of $\mathrm{Si}, \mathrm{Ti}, \mathrm{Fe}$ admixtures, it can be seen that the powders after the RMA have irregularly shaped particles agglomerated together with typical morphology of powdery structures. There is a wide distribution of particles in sizes ranging from 0.1 to $0.8 \mu \mathrm{m}$. It has been established that the uniformity of the particles in size increases for samples with a high content of silicon. The content of particles with an average size of $0.1-0.5 \mu \mathrm{m}$ in an alloy of $10 \mathrm{wt}$. \% Si is $70 \%$ (Fig. 3, e, f), while in alloys with 5 wt. \% Si the content of such particles is approximately $30 \%$ (Fig. 3, a-d). Silicon in composites in the process of grinding helps to grind the particles of the formed magnesium hydride due to its natural strength. In powders of an alloy of $10 \mathrm{wt}$ \% $\mathrm{Si}$ after the first cycles of their hydrogenation/ dehydrogenation (Fig. 3,f), there is a smaller quantity of large agglomerates, while in samples of mechanical alloys with 5 wt. \% Si (Fig. 3,b, d) the quantity of such agglomerates is bigger.

\subsection{Thermal behavior of the mechanical alloys- composites \\ Hydrogen desorption isobars of the MA1-MA4} samples at their first heating after RMA synthesis are shown in Fig. 4, and those recorded for the samplers after first hydrogenation from the gas phase are presented in Fig. 5. It should be paid attention to the conditions of their production: all isobars were obtained at constant pressure of hydrogen in the reactor $(0.1 \mathrm{MPa})$ and sample heating rate was $3{ }^{\circ} \mathrm{C} / \mathrm{min}$. The mass of samples of all MAs was $0.15 \mathrm{~g}$. The isobars shown in Fig. 3 and Fig. 4 were used to determine the beginning temperature $\left(\mathrm{T}_{\text {beg. }}\right.$ ) of hydrogen desorption from hydride phase $\mathrm{MgH}_{2}$ of MA1-MA4 and their hydrogen 
The Influence of Complex Doping on Kinetics of Decomposition...
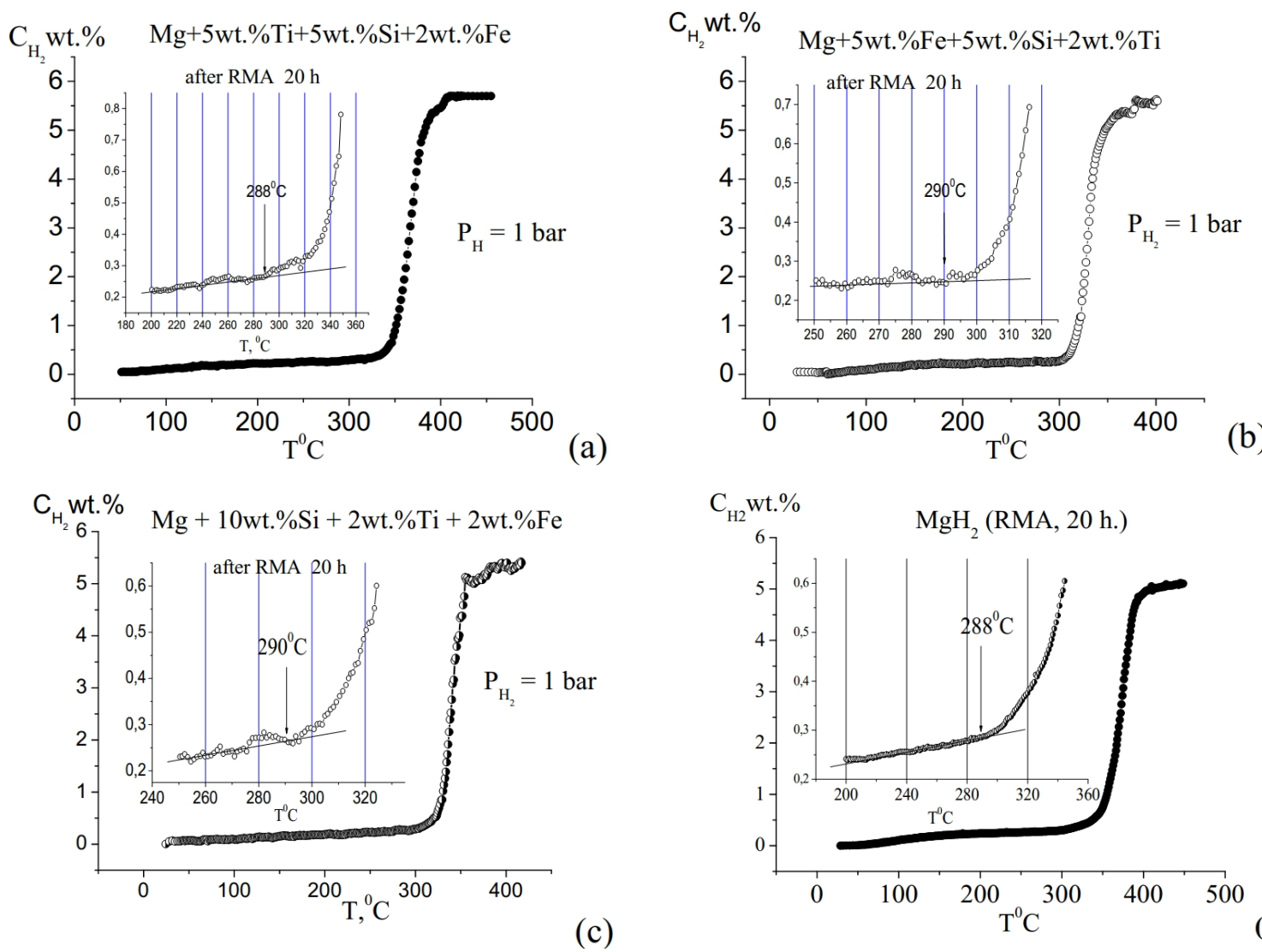

Fig. 4. Isobars of hydrogen desorption $\left(P_{\mathrm{H} 2}=0.1 \mathrm{MPa}\right)$ from the hydride phase $\mathrm{MgH}_{2}$ of the mechanical alloys in the case of its first heating (after reactive mechanical alloying for 20h): a - MA1; b - MA2; c - MA3; d - MA4.

Table 3

Hydrogen desorption from MA in the case of its first heating after mechanochemical synthesis (RMA) and its first hydrogenation from the gaseous phase (HGM)

\begin{tabular}{|l|c|c|c|c|}
\hline \multirow{2}{*}{$\begin{array}{c}\text { Mechanical } \\
\text { alloy-composite, wt. \% }\end{array}$} & \multicolumn{2}{|c|}{ 1-st desorption after RMA } & \multicolumn{2}{|c|}{$\begin{array}{c}\text { 1-st desorption } \\
\text { after HGM }\end{array}$} \\
\cline { 2 - 5 } & $\mathrm{T},{ }^{0} \mathrm{C}$ & $\mathrm{C}_{\mathrm{H} 2}$, wt. \% & $\mathrm{T},{ }^{0} \mathrm{C}$ & $\mathrm{C}_{\mathrm{H} 2}$, wt. \% \\
\hline $\mathrm{MC} 1 \mathrm{Mg}+5 \mathrm{Si}+5 \mathrm{Ti}+2 \mathrm{Fe})$ & 288 & 5.7 & 288 & 5.3 \\
\hline $\mathrm{MC} 2(\mathrm{Mg}+5 \mathrm{Si}+5 \mathrm{Fe}+2 \mathrm{Ti})$ & 288 & 5.6 & 310 & 5.5 \\
\hline $\mathrm{MC} 3(\mathrm{Mg}+10 \mathrm{Si}+2 \mathrm{Fe}+2 \mathrm{Ti})$ & 290 & 5.4 & 310 & 4.1 \\
\hline $\mathrm{MC} 4\left(\mathrm{MgH}_{2}\right)$ & 288 & 5.1 & 320 & 6.3 \\
\hline
\end{tabular}

capacities. The obtained data are shown in Table 3. After obtaining the curves of the first desorption of hydrogen from the MA samples shown in Figure 4, the samples were not removed from the reactor. At $400{ }^{\circ} \mathrm{C}$, hydrogen pressure of $6 \mathrm{MPa}$ was in the reactor. During the sample cooling together with the furnace its first (and subsequent) hydrogenation from the gas phase took place. From Figs. 4 and 5 and Table 3, it is obvious that the temperature of the beginning of hydrogen release from the hydride phase $\mathrm{MgH}_{2}$ of MA1, MA2, MA3 composites after RMA was 288, 290, $290{ }^{\circ} \mathrm{C}$, respectively. After their first hydrogenation from the gas phase, the temperature was $288,313,310{ }^{0} \mathrm{C}$, respectively. If one compares $\mathrm{T}_{\text {beg }}$ of the release of hydrogen from the unalloyed $\mathrm{MgH}_{2}$ phase of MA4 $\left(288{ }^{\circ} \mathrm{C}\right)$ with the same temperature for MA1, MA2, $\mathrm{MA} 3$, one can states that the addition of $\mathrm{Si}, \mathrm{Ti}$ and $\mathrm{Fe}$ to magnesium practically does not reduce the thermal stability of $\mathrm{MgH}_{2}$ of all MAs and, consequently, does not reduce the temperature of the beginning of hydrogen desorption. In our opinion, the explanation of this can be the fact that in the conditions of our method of obtaining of MAs does not form a solid solution in magnesium $\mathrm{Si}$, $\mathrm{Ti}, \mathrm{Fe}$, whose hydride is $\mathrm{Mg}(\mathrm{Si}, \mathrm{Ti}, \mathrm{Fe}) \mathrm{H}_{2}$, according to [5], should have a lower formation enthalpy and a lower thermodynamic stability and decomposition temperature of $\mathrm{MgH}_{2}$. The evidence of the fact that $\mathrm{Mg}(\mathrm{Si}, \mathrm{Ti}, \mathrm{Fe}) \mathrm{H}_{2}$ hydride was not derived (or its quantity is rather minor) can be, in accordance with the XRD data (see Table 1), the presence in the composite of $\mathrm{TiH}_{2}$ and a significant 


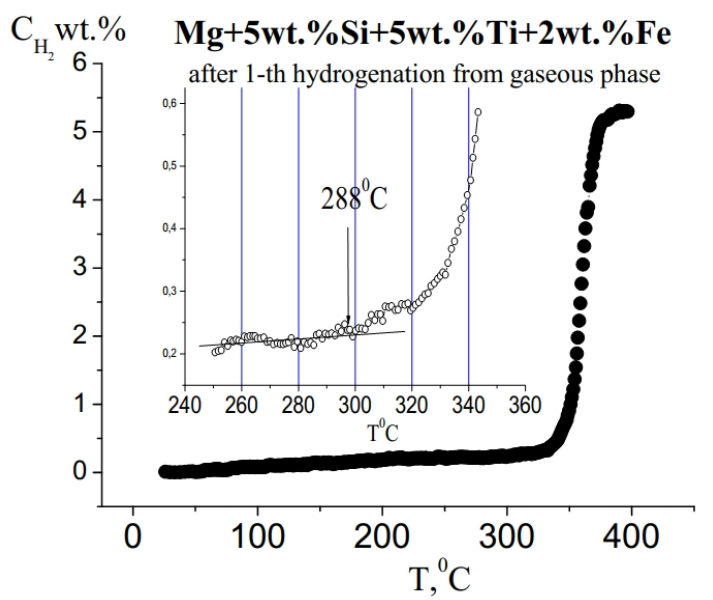

(a)

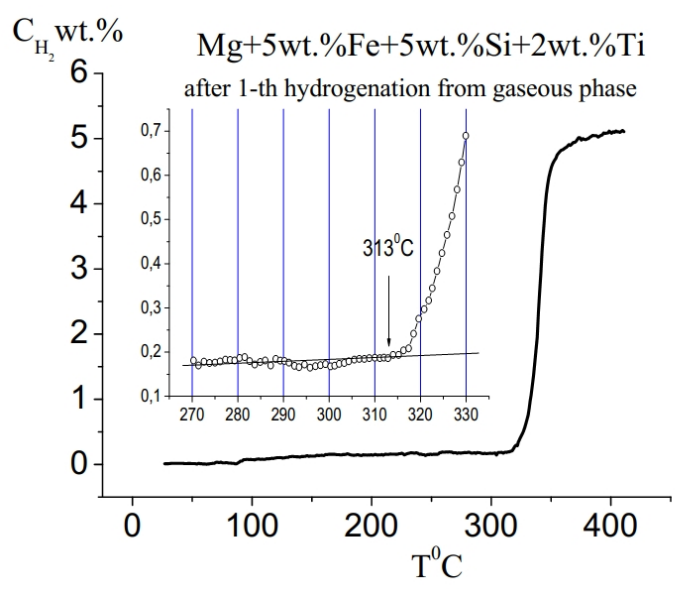

$\mathrm{C}_{\mathrm{H}_{2}}$ wt. $\% \quad \mathrm{Mg}+10 \mathrm{wt} . \% \mathrm{Si}+2 \mathrm{wt} . \% \mathrm{Ti}+2 \mathrm{wt} . \% \mathrm{Fe}$

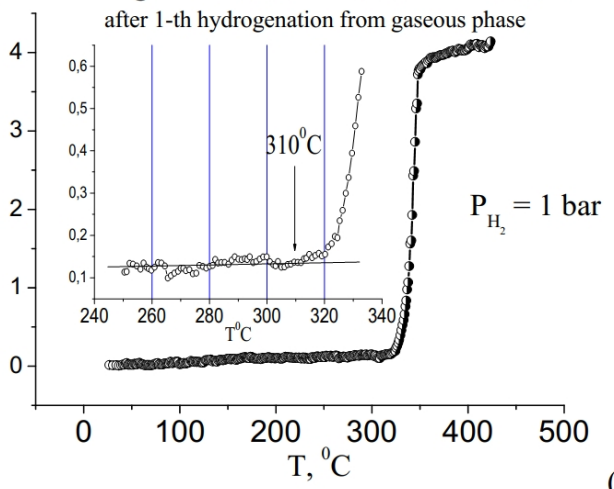

(c)

Fig. 5. Isobars of hydrogen desorption from the $\mathrm{MgH}_{2}$ hydride phase of the mechanical alloys after their first hydrogenation from the gaseous phase (for a heating rate of $3^{\circ} \mathrm{C} / \mathrm{min}$ under a hydrogen pressure of $0.1 \mathrm{MPa}$ ): $\mathrm{a}-\mathrm{MA} 1 ; \mathrm{b}-\mathrm{MA} 2 ; \mathrm{c}-\mathrm{MA} 3$.

Table 4

Time (min.) of desorption of half $\left(\tau_{1 / 2}\right)$ and full $\left(\tau_{\mathrm{f}}\right)$ hydrogen amount from $\mathrm{MgH}_{2}$ hydride phase at $310{ }^{\circ} \mathrm{C}$ and $330{ }^{\circ} \mathrm{C}$

\begin{tabular}{|l|l|c|c|c|}
\hline \multirow{2}{*}{$\begin{array}{c}\text { Mechanical alloy-composite, } \\
\text { wt. } \%\end{array}$} & \multicolumn{2}{|c|}{$310{ }^{\circ} \mathrm{C}$} & \multicolumn{2}{c|}{$330{ }^{0} \mathrm{C}$} \\
\cline { 2 - 5 } & $\tau_{1 / 2}$ & $\tau_{\mathrm{f}}$ & $\tau_{1 / 2}$ & $\tau_{\mathrm{f}}$ \\
\hline MA1 $(\mathrm{Mg}+5 \mathrm{Ti}+5 \mathrm{Si}+2 \mathrm{Fe})$ & 45 & 90 & 14 & 30 \\
\hline MA2 $(\mathrm{Mg}+5 \mathrm{Si}+5 \mathrm{Ti}+2 \mathrm{Fe}$ & 25 & 48 & 12 & 28 \\
\hline MA3 $(\mathrm{Mg}+10 \mathrm{Si}+2 \mathrm{Ti}+2 \mathrm{Fe}$ & 11,5 & 20 & 6,3 & 10 \\
\hline MA 4 (MgH$)$ & 88 & 130 & 31 & 75 \\
\hline
\end{tabular}

content of pure $\mathrm{Si}$ and $\mathrm{Fe}$ phases (the latter phases are formed due to substantial amounts of the alloying elements $\mathrm{Si}$, Ti and Fe). As can be seen from Table 2, the absence of the expected decrease in volume of the unit cell of hydride phase $\mathrm{MgH}_{2}$ of the composites MA1, MA2, and MA3 compared with that of the same hydride phase of the composite MA4 can also be an indication of the absence of formation in our synthesis conditions of $\mathrm{Mg}(\mathrm{Si}, \mathrm{Ti}, \mathrm{Fe}) \mathrm{H}_{2}$ hydride. From data listed in Table 3, it is worth noting a decrease of hydrogen capacity in the composites MA1, MA2, and MA3 after their hydrogenation from the gas phase. In the case of the composites MA2 and MA3, a slight increase in the temperature of the beginning of hydrogen desorption from $290{ }^{\circ} \mathrm{C}$ to $310{ }^{\circ} \mathrm{C}$ and MA4 to $320{ }^{\circ} \mathrm{C}$. In our opinion, the mentioned increase in temperature may be caused by the absence of a phase of pure silicon, which possesses the effect of destabilization of $\mathrm{MgH}_{2}$ and contributes to a decrease in the decomposition temperature, and a significant increase in the amount of $\mathrm{Mg}_{2} \mathrm{Si}$ phase in the composites MA2 and MA3 after their hydrogenation from the gas phase. It should be noted that as a result of 4-10 cycles of hydrogenation / dehydrogenation of the composites MA1, MA2 and MA3 from the gas phase, we did not observe significant changes in the nature of the desorption curves and their position in the temperature scale. This may indicate reversibility of the process of cyclic hydrogenation / dehydrogenation of the obtained MAs and the absence of significant degradation of their hydrogen adsorption properties.

\subsection{Mechanical alloys hydrogen desorption kinetics process}

Hydrogen desorption kinetics from $\mathrm{MgH}_{2}$ hydride phase of all MAs after their hydrogenation from the gas phase under the same conditions has been investigated at $310{ }^{\circ} \mathrm{C}$ and $330{ }^{0} \mathrm{C}$. Hydrogen desorption kinetic curves are presented in Fig. 6. All curves were obtained at a constant hydrogen pressure of $0.1 \mathrm{MPa}$ in the reactor. The data of hydrogen time release of half of hydrogen quantity $\left(\tau_{1 / 2}\right)$ and total hydrogen quantity $\left(\tau_{t}\right)$ for all 

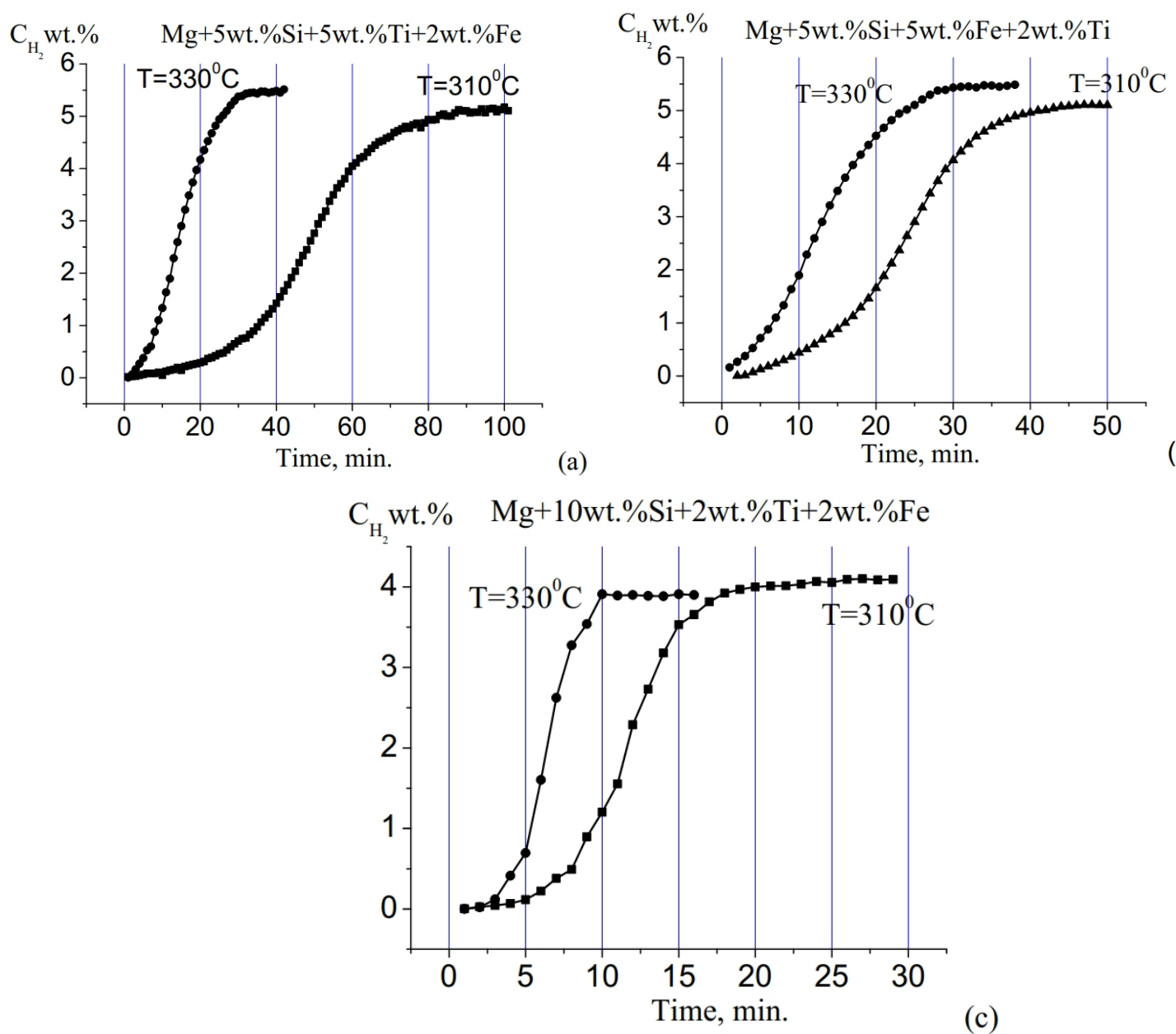

(c)

Fig. 6. Kinetic curves of hydrogen desorption at temperature 310 and $330{ }^{\circ} \mathrm{C}$ from the $\mathrm{MgH}_{2}$ hydride phase of the mechanical alloys: a - MA1; b-MA2; c-MA3; d-MA4.

MAs are shown in Table 4. As we can see from Table 4 and kinetic curves presented in Fig. 6, MA3 mechanical alloy-composite has the best kinetics of hydrogen desorption from $\mathrm{MgH}_{2}$. The composite MA1 possesses the worst kinetics. If one compare the kinetic curves of the composites MA1, MA2 and MA3 presented in Figs. 6, a-c with the kinetic curve of MA4 (Fig. 6d), one can see a significant difference in time that is necessary for the release of all hydrogen at temperature of $330{ }^{\circ} \mathrm{C}$. The comparison shows that the addition of $\mathrm{Si}$, Ti and $\mathrm{Fe}$ to magnesium significantly improves the kinetics of hydrogen desorption from hydride phase $\mathrm{MgH}_{2}$ in all MAs, and the fast process of hydrogen desorption has been provided by the addition $10 \mathrm{wt} . \% \mathrm{Si}+2 \mathrm{wt} . \% \mathrm{Ti}+$ 2 wt. Fe. In our opinion, $\mathrm{Fe}$ and $\mathrm{Ti}$ play the main role in improving the kinetics of hydrogen desorption in the composites MA1 and MA2. They possess high catalytic properties and favor recombination of hydrogen on the particle surface of the hydride phase, and, consequently, reduce its thermal stability. Si plays a significant role also in improving the kinetics of the process of hydrogen desorption in MA3, whose content in the addition to $\mathrm{Mg}$ 5 times higher than the contents of titanium or iron. Silicon does not possess such high catalytic properties as titanium and iron and does not affect the chemical state of the particle surface as $\mathrm{Ti}$ and Fe. However, in the process of reactive grinding silicon acts as an effective dispersive element and it helps to reduce the average grain size of hydride phase $\mathrm{MgH}_{2}$ of the MAs, and, as a result, improves the kinetics of hydrogen desorption process. Confirmation of such conclusion can be the results of microstructure studies of all MAs. The smallest average grain size of the hydride phase $\mathrm{MgH}_{2}$ is detected in MA3, where the content of silicon is the highest, and the kinetics of the hydrogen desorption process is the best (Tables 1 and 4).

\section{Conclusion}

The new alloys-composites with reduced thermal stability and improved kinetics of the decomposition of their hydride phase $\mathrm{MgH}_{2}$ were synthesized by the reactive grinding in the hydrogen atmosphere of a mixture of $\mathrm{Mg}$ powder with different content of additives $\mathrm{Ti}, \mathrm{Fe}$ and $\mathrm{Si}$. The influence of alloying elements $\mathrm{Si}$, Ti, Fe on the hydrogen sorption properties, thermal stability and kinetics of the hydrogen desorption process from the hydride phase $\mathrm{MgH}_{2}$ of the obtained MAs has been studied. It was established that the addition of $\mathrm{Ti}, \mathrm{Fe}$ and Si to magnesium leads to a significant improvement in the kinetics of hydrogen desorption from the hydride phase $\mathrm{MgH}_{2}$ of the obtained MAs, as evidenced by the experimentally recorded significant reduction in time of 
the half and total quantity of desorbed hydrogen. The reduction of the thermodynamic stability of $\mathrm{MgH}_{2}$ hydride due to its doping by $\mathrm{Si}, \mathrm{Ti}$, and $\mathrm{Fe}$ was not detected. Results of the present study can be used in the development of new hydrogen sorbent materials for hydrogen energy.

\section{Conflict of interest}

The authors confirm that this article content has no conflict of interest. All authors have approved the final article.

\section{Acknoledgements}

We thank A. Koval for him help with SEM measurements.

Ershova O.G. - Senior Researcher, Ph.D. in Technical Sciences;

Dobrovolsky V.D. - Senior Researcher, Ph.D in Physical and Mathematical Sciences;

Solonin Yu.M. - Grand PhD in Physical and Mathematical Sciences, Academician of NASU.

[1] A. Bassetti, E. Bonetti, L. Pasquini, A. Montone, J. Grbovic, V. Antisari, J. Eur. Phys. B 43, 19 (2005) (doi: 10.1140/epjb/e2005-00023-9.)

[2] J.-L. Bobet, E. Akiba, B. Darriet, Int. J. Hydrogen Energy 26, 493(2001) (doi:10.1016/S0360-3199(00) 00082-3).

[3] S.-N. Kwon, S.-H. Baek, R. D. Mumm, S.-H. Hong, M.-Y. Song, Int. J. Hydrogen Energy 33, 4586 (2008) (doi:10.1016/j.ijhydene. 2008.05.097).

[4] J. Mao, Z. Guo, X. Yu, H. Liu, Z. Wu, Int. J. Hydrogen Energy 35, 4569 (2010) (doi: 10.1016/j.ijhydene.2010.02.107).

[5] C.X. Shang, M. Bououdina, Y. Song, Z.X. Guo, Int. J. Hydrogen Energy 29, 73 (2004) (doi:10.1016/S0360-3199(03)00045-4).

[6] O.G. Ershova, V.D. Dobrovolsky, Yu.M. Solonin, O.Yu. Khyzhun, A.Y. Koval, J. Alloys Compound 464 212 (2008) (doi:10.1016/j.jallcom.2007.10.064).

[7] O. Ershova, V. Dobrovolsky, R. Morozova, Yu. Solonin, Hydrogen Materials Science and Chemistry of Carbon Nanomaterials (T.N. Veziroglu (Ed.), Springer, Dordrecht, 2007).

[8] O. Ershova, V. Dobrovolsky, Yu. Solonin, Carbon Nanomaterials in Clean Energy Hydrogen Systems (B. Baranowski (Ed) Springer Science + Business Media B.V., 2008).

[9] R.Sh. Rohit, P.T. Anand, M.A. Shaz, O.N. Srivastava, Int. J. Hydrogen Energy 38, 2778 (2013) (doi:10.1016/j.ijhydene.2012.11.073).

[10] Z. Degouche, J. Goyette, T.K. Bose, R. Schulz, Int. J. Hydrogen Energy 28, 983 (2003) (doi.org/10.1016/S0360-3199(02)00196-9).

[11] J. Huot, J.F. Pelletier, L.B. Lurio, M. Sutton, R. Schulz, J. Alloys Compound 348, 319(2003) (doi:10.1016/S0925-8388(02)00839-3).

[12] W. Oelerich, T. Klassen, R. Borman, J. Alloys Comp. 315, 237(2001) (doi.org/10.1016/S09258388(00)01284-6).

[13] Xi Chen, Jianxin Zou, Shuqing Huang, He Guangli, Ning Zhao, Xiaoqin Zeng, Wenjiang Ding, RSC Adv. 8, 18959 (2018) (doi: 10.1039/c8ra01963k).

[14] E. David, J. Achiev. Mat. Manufact. Eng. 20, 87 (2007).

[15] V.D. Dobrovolsky, O.G. Ershova, Yu.M. Solonin, O.Y. Khyzhun, V. Paul-Boncour, J. Alloys Comp. 465, 177 (2008) (doi:10.1016/j. jallcom. 2007 .10.125).

[16] M. Polanski, J. Bystrzycki J. Alloys Compd. 486, 697 (2009) (doi:10.1016/j. ijhydene.2009.06.02).

[17] J.-C. Crivello1, B. Dam, R.V. Denys, M. Dornheim, D.M. Grant, Appl.Phys. A 122, 97 (2016) (doi:10.1007/s00339-016-9602-S).

[18] T. Sabitu, G. Gallo, A.J. Goudy, J. Alloys Compd. 499, 35(2010) (doi:10.1016/j.Jallcom.2010.03. 128).

[19] M. Tian, C. Shang J. Chem. Technol. Biotechnol. 86, 69 (2011) (doi:10.1002/jctb.2479).

[20] M. Sherif El-Eskandarany, H.S. AlMatrouk, Ehab Shaban, Ahmed Al-Duweesh, Materials Today: Proceedings 3, 2608(2016).

[21] C.X. Shang, Z.X. Guo J.Power Sources 129, 73 (2004) (doi:10.1016/j.jpowsour. 2003.11.013).

[22] S.N. Klyamkin, B.P. Tarasov, E.L. Straz, R.V. Lukashev, I.E. Gabis, E.A. Evard, A.P. Voyt, Int. Sci. J. Alternat. Energy Ecol. 1 (21), 27 (2005).

[23] T. Spassov, V. Rangelova, P. Solsona J. Alloys Compd. 398, 139 (2005) (doi:10.1016/j.jallcom. 2005.02.035).

[24] P. Delchev, P. Solsona, B. Drenchev, J. Alloys Compd. 388, 98 (2005)103 (doi:10.1016/j.Jall com. 2004. 07.001).

[25] A. Ming, Mater. Sci. Eng. B 117, 37(2005) (doi:10.1016/j.mseb.2004.10.017).

[26] A. Montone, J. Grbovič, A. Bassetti Int. J. Hydrogen Energy 31, 2088 (2006) (doi: 10.1016/j. ijhydene.2006.01.020).

[27] Z.G. Huang, Z.P. Guo, A. Calka, J. Alloys Compd. 427, 94 (2007) (doi:10.1016/j.jallcom. 2006. 03.069). 
[28] M.A. Lillo-Ródenas, Z.X. Guo, K.F. Aguey-Zinsou, Carbon 46, 126 (2008) (doi:10.1016/j.carbon. 2013.01.058).

[29] O.G. Ershova, V.D. Dobrovolsky, Yu.M. Solonin, O.Yu. Khyzhun, A.Yu. Koval, Materials Chemistry and Physics 62, 408 (2015) (doi:10.1016/j.matchemphys.2015.06.007).

[30] K.G. Bambhaniya, G.S. Grewal, V. Shrinet, N.L. Sindh, T.P. Govindan, Int. J. Hydrogen Energy 37 , 3671 (2012) (doi:10.1016/j.ijhydene.2011.04.099).

[31] O.G. Ershova, V.D. Dobrovolsky, Yu.M. Solonin, Fiz. Khim. Tverd. Tila 14 (1), 101 (2013).

[32] M. Bououdina, Z.X. Guo, J. Alloys Comp. 336, 222 (2002) (doi:10.1016/S0925-8388(01)01856-4).

[33] M. Tanniru, D.K. Slattery, F. Ebrahimi, Int. J. Hydrogen Energy 35, 3555 (2010) (doi:10.1016/j.ijhydene. 2010.01.109).

[34] M. Tanniru, D.K. Slattery, F. Ebrahimi, Int. J. Hydrogen Energy 36, 639 (2011) (doi:10.1016/j.ijhydene.2010.09.083).

[35] C. Zhou, Z. Z. Fang, J. Lu, X. Luo, C. Ren, P. Fan, Y. Ren, and X. Zhang, J. Phys. Chem. C118, 11526 (2014) ( doi:10.1021/ jp501306w).

[36] S. Bouaricha, L.P. Dodelet, D.Guay, J.Huot, S.Boily, R.Schulz, J. Alloys Compd. 297, 282 (2000) doi:10.1016/S0925-8388(99)00612-X.

[37] J.F. Stampfer, C.E. Holley, J.F. Suttle, J. Amer. Chem. Soc. 82, 3504 (1960) (doi:10.1021/ja01499 a006).

[38] O.G. Ershova, V.D. Dobrovolsky, O.Yu. Khyzhun, Yu.M. Solonin, Physics and chemistry of solid state 12 (4), 1044 (2011).

[39] John J. Vajo, J. Phys. Chem. B 108, 13977 (2004) (doi:10.1021/jp040060).

[40] M. Polanski, J. Bystrzycki, Int. J. Hydrogen Energy 34, 7692 (2009) (doi:10.1016/jihydene2009.06 002).

[41] D.A. Paskevicius, A. Sheppard, C.J. Chaudhary, C.J. Webb, E. Mac, A. Gray, H.Y. Tian, V.K. Peterson, E. Buckley, J. of Hydrogen Energy 36, 10779 (2011) (doi:10.1016/j.ijhydene.2011.05.132).

[42] Motoki Shimada, Hisashi Tamaki, Eiji Higuchi, J. of Materials and Chemical Engineering Jul. 2(3), 64 (2014).

[43] Anna-Lisa Chaudhary, M. Paskevicius, D.A. Sheppard, J. Alloys Compd. 623, 109 (2015) (doi.org/10.1016/j.jallcom.2014.10.086).

[44] J. Crivello, R.V. Denys, M. Dornheim, M. Felderhoff, D.M. Grant, J. Huot, T.R. Jensen, P.De Jongh, M. Latroche, G.S. Walker, C.J. Webb, V.A. Yartys, Appl. Phys. A 122, 85 (2016) (doi:10.1007/s00339-0169601-1).

\author{
О.Г. Єршова, В.Д. Добровольський, Ю.М. Солонін
}

\title{
Вплив комплексного легування на кінетику розкладу та термічну стабільність механічних сплавів на основі Мg
}

\author{
Інститут проблем матеріалознавства ім. І.М. Францевича НАН Украӥни, Київ, \\ Україна, е-mail:dobersh2017@ukr.net
}

\begin{abstract}
Механічні сплави (МС) були синтезовані методом реактивного механічного сплавлення. При тиску водню 0,1 МПа 3 використанням термодесорбціонної спектроскопії були вивчені термостабільність, кінетика десорбції водню з гідридної фази $\mathrm{MgH}_{2}$ отриманих МС. Встановлено, що комплексне легування $\mathrm{Fe}, \mathrm{Si}$, Тi призводить до значного поліпшення десорбції водню з гідридної фази $\mathrm{MgH}_{2} \mathrm{MC}$, синтезованих методом реактивного механічного сплавлення (РМС). Воднева ємність після реактивного подрібнення протягом 20 год. дорівнювала 5,7\% ваг. Внаслідок цього легування зниження термодинамічної стабільності $\mathrm{MgH}_{2}$ не встановлено. Випробувані матеріали показали високий потенціал як сплавів для зберігання водню, особливо для стаціонарного застосування.
\end{abstract}

Ключові слова: механічний сплав, воденьсорбційні властивості, термічна стійкість, кінетика. 